V.F. Syvokobylenko, Dr. Sc. (Tech.), Prof., orcid.org/0000-0002-7720-0540, V.A. Lysenko, Cand. Sc. (Tech.), orcid.org/0000-0002-6411-3114
Donetsk National Technical University, Pokrovsk, Donetsk Oblast, Ukraine, e-mail: svf1934@gmail.com; viktor.lysenko@donntu.edu.ua

\title{
EARTH FAULT PROTECTION FOR COMPENSATED ELECTRIC NETWORKS BASED ON FREQUENCY FILTERS
}

Purpose. Development of selective microprocessing earth fault protection in compensated electrical networks of 6-35 kV. Use of the Goertzel algorithm for the separation of components of frequencies higher than fundamental frequency from the zero sequence voltage and currents.

Methodology. The methods of mathematical modeling and analysis of transients in compensated electric networks of 6-35 kV, Fourier transform and Goertzel algorithm, construction of earth-fault protection algorithms, and experimental research are used.

Findings. The results of mathematical modeling show that in compensated electric networks of 6-35 kV at phase-to-ground fault the reactive power direction in a in a damaged feederlcan be similar to the one in an undamaged feeder1; therefore, conventional protections cannot perform selective operation. This action can be provided by protections based on separation of components of fixed frequencies of $200-300 \mathrm{~Hz}$ from the zero sequence voltage and currents. Their reactive power in an undamaged connection is always directed off tyres, because is hardly compensated by the reactor regardless of degree of its cavity tuning. When applying band-pass frequency filters, the required protection responsivity is not always provided at phase-to-ground fault through resistances exceeding 10-15 Ohm. Moreover, failure of steady operation of filters is possible due to location of their poles on a circular curve of a unit radius, while use of blocks of numerical differentiation of current and voltage can result in running failure at alternate arcing ground. The application of the Goertzel algorithm for high-frequency components detection is proposed. It is implemented through an infinite impulse-response filter of the second order with two real coefficients in back coupling and one complex coefficient in circuit of direct relation. The results of simulation of the behavior of protection in the system of computer algebra Mathcad confirmed the reduction of calculation costs and stable work, regardless of the presence of aperiodic components at different initial phases of the voltage at the time of fault. As part of the protection, a trigger unit is provided that allows the operation if the voltage of the zero sequence exceeds the setpoint, which is $12-15 \%$ of the nominal value. In order to ensure reliable operation of the protection, permanent and arcing faults provide activation of protection impulses in the event of a fault. The positive results of protection algorithm were achieved on the mathematical model of the network as well as when testing a microprocessor prototype of a protective system in a laboratory environment.

Originality. For the first time for ground-fault protection in $6-35 \mathrm{kV}$ compensated networks, it is proposed to separate components of frequencies higher than fundamental frequency from the zero sequence voltage and currents using frequency filters created on the basis of the Goertzel algorithm are proposed; the algorithm is an improved modification of the Fourier transform; this increased the sensitivity, speed and stability of work protection.

Practical value. The mathematical model of the compensated electric network allows analyzing the behavior of protection at permanent and arcing ground faults. Selective protection from phase faults on the ground has been developed, which allows increasing the reliability of the power supply systems with a voltage of $6-35 \mathrm{kV}$.

Keywords: compensated network, mathematical model, ground fault, selective protection, frequency filter, Fourier transform, Goertzel algorithm

Introduction. Electric networks with a voltage of $6-35 \mathrm{kV}$ are the basis of power supply systems for industrial, mining and agricultural enterprises, cities, and own needs of power plants. Such networks are used to connect renewable energy sources. Networks with a voltage of $6-35 \mathrm{kV}$ work with nonearthed neutral. To reduce the current of a single-phase earth fault in such networks, a Petersen coil is used. The Petersen coil significantly reduces the current of a single-phase earth fault, and also significantly changes the nature of the transient process after breaking a single-phase circuit (for example, after the extinction of an electric arc), which reduces the level of overvoltage. A side issue with the use of the Petersen coil is the deterioration of the working conditions of single-phase earth fault protection. Such protection systems generally react to zero sequence voltage of the network and zero sequence current in a certain feeder of the power supply system. Thus, the problem of constructing reliable selective earth fault protection is relevant and is being actively studied in a professional environment $[1,2]$.

Literature review. The number of publications related to earth faults in compensated networks is large and steadily increasing. The scientific community responds to this by trying to systematize and classify various approaches and methods for solving the problem of earth fault protection [1-3]. A wide range of techniques is used to identify a damaged feeder. There

(C) Syvokobylenko V. F., Lysenko V.A., 2020 were attempts to solve the problem of earth fault protection by refusing to use the Petersen coil and grounding the neutral of the network through a resistor. Investigations into faultyphase-earthing are ongoing [4]. Work is underway to create electric arc models and to simulate single-phase earth faults using various software products [5]. It was proposed to use a wide range of digital signal processing methods, as well as a genetic algorithm, methods of fuzzy logic, neural networks, deep learning, gray systems, mixed atom libraries, and various combinations of them [6].

In our opinion, the classical protection algorithms, for example, a power direction relay or an admittance-based relay to earth fault protection have room for further improvement. However, for the proper operation of such protections, certain conditions are required. Illustrative in this regard, for example, is a paper [7] in which a multi-frequency admittance-based relay is considered. The idea of analyzing currents and voltages not only at the industrial frequency $(50 \mathrm{~Hz})$ deserves special attention.

Recently, a number of works on creating selective compensations for compensated networks [7, 8], based on selecting their components of a fixed frequency, several times higher than the fundamental frequency from the currents and voltages of zero sequence have appeared. It was shown in [9] that such a frequency can be taken from the range of $150-350 \mathrm{~Hz}$, since the Petersen coil has large impedance and hardly affects the distribution of capacitive currents in the network at such 
frequencies. In $[8,9]$, for directional earth fault protection, components of the frequency of $220 \mathrm{~Hz}$ are extracted from currents and voltages of the zero sequence using narrow-band frequency filters, and then the direction of the reactive power is determined from them and the damaged connection is detected. Despite the shortcomings in [9] regarding the choice of the band-pass filter parameters and the construction of protection algorithms, this approach turned out to be very promising. In [10], it was proposed to improve such protection by performing it two-channel, more stable and sensitive due to the use of filters with improved characteristics and differentiation units for currents and voltages in order to obtain their orthogonal components. The disadvantage of this protection is the lack of sensitivity during earth faults through resistances of more than $10-15$ ohms.

Unsolved aspects of the problem. In the protection algorithm proposed in [9], the authors use second-order recursive frequency filters that are on the verge of stability. Such filters have low stability and in the event of "pecks" to the ground in the network, they switch to the self-excitation mode, which can cause a false protection operation. In addition, the filters in the current and voltage circuits in order to ensure a 90-degree angular shift between their output signals with different transfer functions and amplification factors are selected, which introduces additional errors in the protection output signals. In addition, the reactive power in the zero sequence circuit pulsates, which requires further processing of the power pulses and, accordingly, increase in the delay. In [11], for this type of protection, an attempt was made to determine the orthogonal components of the corresponding frequencies using the Fourier transform, which improved the characteristics of the relay, however, increased its response time in case of fault. Thus, earth fault protection algorithms for compensated networks require further research and improvement.

Purpose. To develop a microprocessor-based selective protection system for compensated electric networks with a voltage of $6-35 \mathrm{kV}$, based on the use of frequency components higher than the industrial frequency in zero sequence currents and voltage. To select the required components, we use frequency filters based on a modified Fourier transform in the form of the Goertzel algorithm.

Methods. Mathematical modeling of processes in power supply systems and protection devices, methods of analysis and development of new principles and protection algorithms.

Results. To analyze the behavior of protection during transients during a fault protection, we use a mathematical model as applied to a typical scheme of a compensated electric network with a voltage of $6 \mathrm{kV}$, the circuit diagram of which is shown in Fig. 1. The mathematical model is described in [10] and consists of differential equations for branches and nodes of the circuit and earth fault protection algorithms. To increase

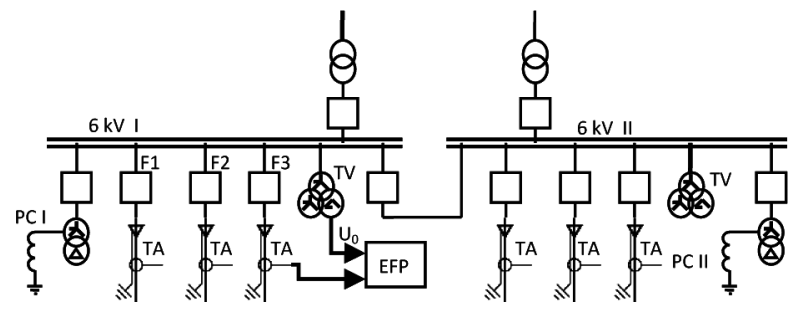

Fig. 1. Schematic diagram of a compensated electrical network $6 \mathrm{kV}$

the numerical stability of the model in it, the solution of differential equations is performed by implicit integration methods.

Earth fault protection (EFP) device is connected to the zero-sequence current transformers TA installed on each feeder, and to the zero-sequence voltage of the voltage transformer TV connected to the busbars. The modeling of processes in the protection units was carried out together with the general network model in accordance with the protection algorithms developed further.

In order to clarify the nature of the distribution of currents and reactive power in the compensated network in the case of earth fault protection for the components of different frequencies, corresponding calculations were performed for the following network parameters. The phase capacitances on the ground of the $F 1-F 3$ feeders were taken equal to 3,8 , and $12 \mu \mathrm{F}$, respectively, interfacial capacitances of $10 \mu \mathrm{F}$, and the resonance inductance of the Petersen Coil Lres $=0.1416$ Hn. The calculations were performed for the earth fault on phase A of the feeder $F 1$ through the active resistance $R c 1=0.2$ Ohms. The insulation resistance to earth in the pre-fault mode was taken equal to $1 \mathrm{MOhm}$.

The results of calculations of currents and reactive power in feeders F1(Iff, Qff), F2(Isf1, Qsf1), F3(Isf2, Qsf2) and in the Petersen Coil (reactor) (Ir, Qr) are shown in the Table below. The calculations were performed at a nominal voltage of $6 \mathrm{kV}$ for various frequencies and for various reactor inductances.

From the data given in the table, it follows that, in all earth fault modes, the currents of intact connections Isp 1 (feeder 2) and Isp 2 (feeder 3 ) are capacitive in nature and are directed towards the buses, while the directions of the currents of the damaged feeder Iff (feeder1) depend on the value of the reactor inductance and voltage frequencies. So, with earth fault and resonant tuning of the reactor at a frequency of $50 \mathrm{~Hz}$, the currents in all connections (Table) are capacitive in nature. In addition, the current in the damaged feeder has a relatively small value $I f f=-10.35 \mathrm{~A}$. For these reasons, selective protection at the industrial frequency is difficult to perform. At the same

The results of calculations of currents and reactive power in feeders

\begin{tabular}{|l|c|c|c|c|c|c|c|c|c|}
\hline \multicolumn{1}{|c|}{$L r, \mathrm{Hn}$} & $f, \mathrm{~Hz}$ & $I f f, \mathrm{~A}$ & $I s f 1, \mathrm{~A}$ & $I s f 2, \mathrm{~A}$ & $I r, \mathrm{~A}$ & Qff, $\mathrm{kVA}$ & $Q s f 1, \mathrm{kVA}$ & $Q s f 2, \mathrm{kVA}$ & $Q r, \mathrm{kVA}$ \\
\hline 0.5 Lres & 50 & -88.25 & -27.15 & -40.81 & 156.2 & -317.5 & -97.71 & -146.8 & 562.1 \\
\hline 0.8 Lres & 50 & -30 & -27.4 & -41.2 & 98.6 & -109.1 & -99.5 & -149.1 & 357.7 \\
\hline Lres & 50 & -10.35 & -27.48 & -41.31 & 79.14 & -37.7 & -100.1 & -150.5 & 289.1 \\
\hline 1.5 Lres & 50 & 16.08 & -27.6 & -41.49 & 53.01 & 58.8 & -100.9 & -151.7 & 193.8 \\
\hline Lres & 100 & 103.2 & -57.46 & -86.96 & 41.22 & 391.7 & -218.2 & -330.2 & 156.7 \\
\hline Lres & 200 & 333.5 & -140.3 & -218.2 & 25.00 & 1530 & -643.4 & -1001 & 114.4 \\
\hline 0.5 Lres & 250 & 487.0 & -206.2 & -327.1 & 46.30 & 2610 & -1104 & -1756 & 250.0 \\
\hline Lres & 250 & 519.6 & -209.8 & -333.4 & 23.60 & 2833 & -1144 & -1818 & 129.9 \\
\hline 1.5Lres & 250 & 530 & -211.1 & -335.1 & 16.20 & 2910 & -1157 & -1840 & 87.00 \\
\hline Lres & 300 & 873.7 & -324.4 & -558.9 & 9.60 & 6618 & -2580 & -4230 & 192.0 \\
\hline
\end{tabular}


time, according to the calculated data, selective protection of the damaged connection can be performed using, for example, frequency filters by extracting signals with a fixed frequency selected from the range of $150-300 \mathrm{~Hz}$. The boundary value of $150 \mathrm{~Hz}$ is due to the exclusion of the influence of the reactor, and the value of $300 \mathrm{~Hz}$ is the simplification of the hardware implementation of the protection. In this case, according to the Shannon theorem, the sampling frequency of the measurement of the input signals should be no less than two times the frequency of the filters, i.e. be more than $600-1000 \mathrm{~Hz}$. When performing the above calculations, the sampling frequency was assumed $1600-2500 \mathrm{~Hz}$, and the step $T$ of a resolution of $0.400-0.625 \mathrm{~ms}$.

The block diagram of the protection algorithm proposed in this work is shown in Fig. 2. It consists of analog-to-digital converters (ADCs) of currents and voltages supplied from current transformers and zero sequence voltage.

The instantaneous discrete values of currents and voltages from the outputs of the ADC are fed to the inputs of Goertzel Discrete Transformation Units (GDTU), which are secondorder IIR filters performed by the Goertzel algorithm and used to obtain complex values of the components of currents $i_{a}+j i_{p}$ and voltages $u_{a}+j u_{p}$ with a selected frequency of, for example, $250 \mathrm{~Hz}$. Then, using the multiplication unit $(\mathrm{X})$, the components of the reactive power $q 1=i_{a} \cdot u_{p}$ and $q 2=i_{p} \cdot u_{a}$, are calculated which then, after the adder, are fed to the threshold detector, where the resulting power $Q=q 1-q 2=i_{a} \cdot u_{p}-i_{p} \cdot u_{a}$ is compared with the given setpoint $Q t$. When the power $Q$ exceeds the setting, the decision relay is activated.

In the proposed protection algorithm, as follows from Fig. 2, to calculate the direction of the reactive power during the earth fault, the orthogonal components of the current and voltage of $200-300 \mathrm{~Hz}$ are required, which must be extracted from the voltages and currents of the zero sequence. Consider the advantages of using for this instead of the discrete Fourier transform (DFT) its modification in the form of the Goertzel algorithm [12]. Suppose, for example, that there are $N(n=1$, $2, \ldots, N)$ measured samples of signal $s(1), s(2), \ldots, s(N)$, for which the spectral sample $S(k)$ for the $k^{\text {th }}$ harmonic ( $k=1$, $2, \ldots, N)$ using DFT and rotary coefficients $W_{N}^{n \cdot k}$ can be expressed as

$$
S(k)=\sum_{n=1}^{N} s(n) \cdot W_{N}^{n \cdot k} ; \quad W_{N}^{n \cdot k}=\exp \left(-j \frac{2 \cdot \pi}{N} n \cdot k\right) .
$$

Rotary coefficients $W_{N}^{n \cdot k}$ are complex quantities and therefore the estimated costs for determining $S(k)$ are large enough, since even with real input signals it is required to perform $2 \mathrm{~N}$ multiplications and $2 \mathrm{~N}$ sums at each step of the calculation. To reduce the estimated costs, and, consequently, increase the speed of protection, we consider the possibility of using the Goertzel algorithm. We will be interested in calculating at each discretization step (in the sliding mode) only one harmonic of the signal with the help of an updated array at each step. To obtain the calculated relations for the Goertzel algorithm, we first represent the calculation of the spectral reference $S(k)$ for the $k^{\text {th }}$ harmonic using the DFT in the form of a filter with the following transfer function

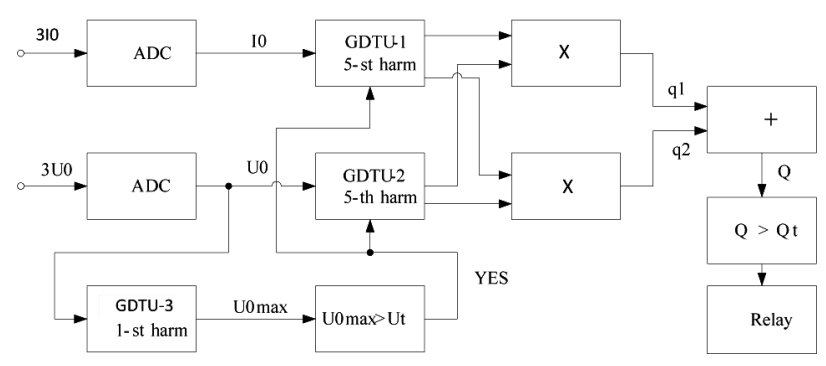

Fig. 2. Goertzel-based protection flowchart

$$
H(z)=\frac{Y(z)}{X(z)}=\frac{W_{N}^{-k}}{1-W_{N}^{-k} \cdot z^{-1}}
$$

After multiplying the numerator and denominator of function (2) by $\left(1-W_{N}^{k} \cdot z^{-1}\right)$ and the corresponding transformations, we obtain the transfer function of the Goertzel algorithm (3) and formulas (4-6) for calculating the spectral count $S(k)$ using intermediate real values of the auxiliary array iteratively calculated at each step $V(r) r=1,2, \ldots, N$

$$
\begin{gathered}
G(z)=\frac{Y(z)}{X(z)}=\frac{W^{-k}-z^{-1}}{1-2 \cos \left(\frac{2 \pi}{N} k\right) \cdot z^{-1}+z^{-2}} ; \\
S(k)=W^{-\mathrm{k}} \cdot V(N-1)-V(N-2) ; \\
V(r)=s(r)+2 \cdot \cos \left(\frac{2 \pi}{N} \cdot k\right) \cdot V(r-1)-V(r-2) ; \\
W^{-k}=\exp \left(j \frac{2 \pi}{N} \cdot k\right) ; \quad \alpha=2 \cdot \cos \left(\frac{2 \pi}{N} \cdot k\right) .
\end{gathered}
$$

The structural diagram of the implementation of the Goertzel algorithm according to $(3,4)$ is shown in Fig. 3.

The scheme contains the recursive part of the calculations (its left part), in which the calculations are performed by the iteration method. Calculations with complex values are performed only once at the last iteration, due to which the estimated costs are almost halved comparing to the DFT, which was confirmed by the calculations using the DFT and Goertzel algorithms shown in Fig. 4 implemented in the MathCad environment.

To evaluate the efficiency of the DFT and Goertzel algorithms using the indicated routines, Figs. 5, $a, b$ show the results of calculations of the fifth and first harmonic in the input voltage containing harmonics $1,5,7$ and 33 .

$$
U(t)=\cos (\omega \cdot t)+0.25 \cdot[\sin (5 \omega \cdot t)+\cos (7 \omega \cdot t)+\cos (33 \omega \cdot t)] .
$$

As follows from Figs. 5, $a, b$, the distinguished harmonics are sinusoidal in spite of the considerable noisiness of the initial voltage. At the same time, the results of calculations for both subprograms practically coincide, which makes it possible to use the Goertzel algorithm as a faster one for earth fault protection.

Simulation of the earth fault in a compensated network (Fig. 1), together with the protection according to the algorithm shown in Fig. 2, was carried out at varying degrees of compensation of capacitive currents by the reactor and at various resistances at the point of earth fault. The number of discrete signals in the current and voltage arrays was taken equal, the calculation step was $0.625 \mathrm{~ms}$, the allocated frequency of the signals to determine the reactive power of $250 \mathrm{~Hz}$. In all cases, a reactive power pulse with duration of about $20 \mathrm{~ms}$ was clearly visible in the initial section of the earth fault, after which it was picked up, subject to the presence of a voltage of $3 \mathrm{U} 0$, and the output relay was triggered.

As example in Figs. 6, $a, b$ and Fig. 7 the results of modeling an arc fault are shown, in which triple ignition and arc extinction occurred, and the ignition occurred at different initial

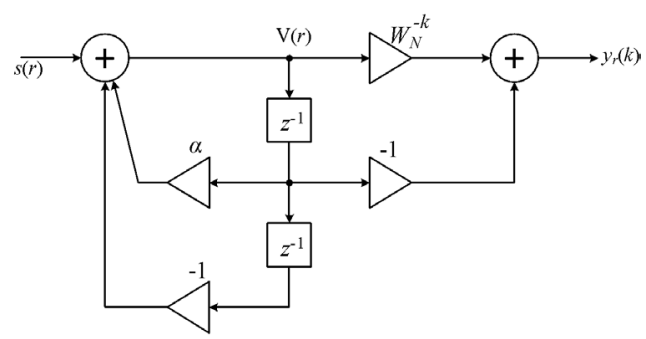

Fig. 3. Goertzel algorithm implementation block diagram 


$$
\operatorname{Gerd}(F I, K):=\mid \begin{aligned}
& X \leftarrow F I \\
& N \leftarrow \operatorname{rows}(X) \\
& K \leftarrow K \\
& \alpha \leftarrow 2 \cdot \cos \left(2 \cdot \frac{\pi}{N} \cdot k\right) \\
& A_{1} \leftarrow X_{1} \\
& A_{2} \leftarrow X_{2}+\alpha \cdot A_{1} \\
& f r \in 3 \cdot N \\
& A_{r} \leftarrow X_{r}+\alpha \cdot A_{r-1}-A_{r-2} \\
& W N k \leftarrow \exp \left(j \cdot 2 \cdot \frac{\pi}{N} \cdot k\right) \\
& \text { Sig } \leftarrow \frac{2}{N} \cdot\left(W N k \cdot A_{N}-A_{N-1}\right)
\end{aligned}
$$

$$
\operatorname{Fur}(F I, K, t):=\mid \begin{aligned}
& X \leftarrow F I \\
& N \leftarrow \operatorname{rows}(X) \\
& K \leftarrow K \\
& N \leftarrow \operatorname{rows}(X) \\
& \operatorname{SigA} \leftarrow \frac{2}{N} \cdot\left[\sum_{i=1}^{N} X I_{i} \cdot \cos \left[t-\frac{2 \cdot \pi \cdot k}{N} \cdot(N-i)\right]\right] \\
& \operatorname{SigP} \leftarrow \frac{2}{N} \cdot\left[\sum_{i=1}^{N} X I_{i} \cdot \sin \left[t-\frac{2 \cdot \pi \cdot k}{N} \cdot(N-i)\right]\right] \\
& \operatorname{Sig} \leftarrow \operatorname{SigA}+i \cdot \operatorname{SigP}
\end{aligned}
$$

Fig. 4. Software modules in the MathCad environment for the implementation of the Goertzel algorithm and Fourier transform
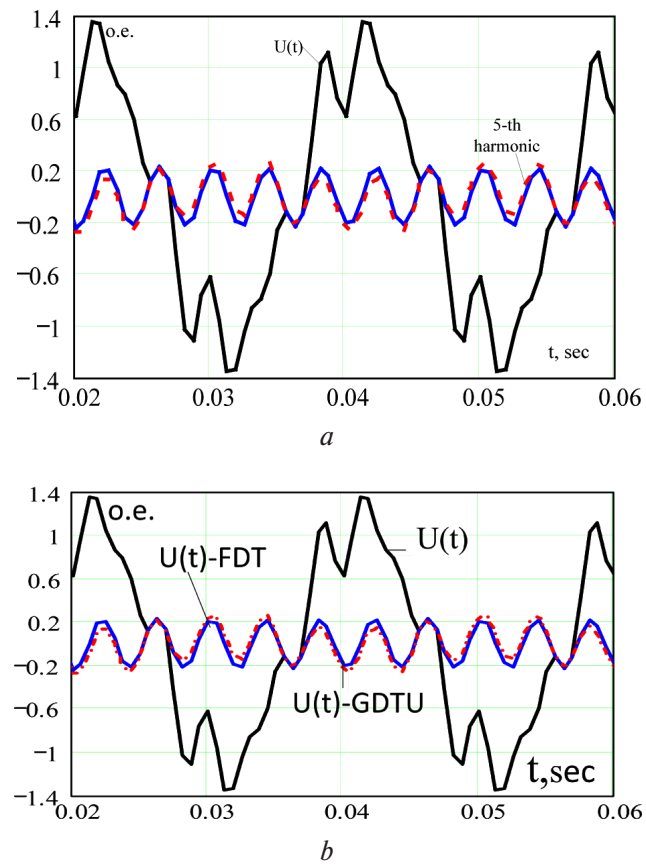

Fig. 5. Results of selection of the $5^{\text {th }}(a)$ and $1^{\text {st }}(b)$ harmonics by DFT and Goertzel algorithm filters

voltages and with different aperiodic components in the earth fault current.

As can be seen from the data above, protection works successfully in all cases. The sensitivity of the protection is sufficient when changing the resistance value in the circuit from $0.1 \mathrm{Ohm}$ to $100 \mathrm{Ohm}$. In the protection of the damaged connection, positive reactive power pulses appear at the beginning of the circuit (Fig. 7), when there is an asymmetry in the current and voltage, including harmonic components of $250 \mathrm{~Hz}$.
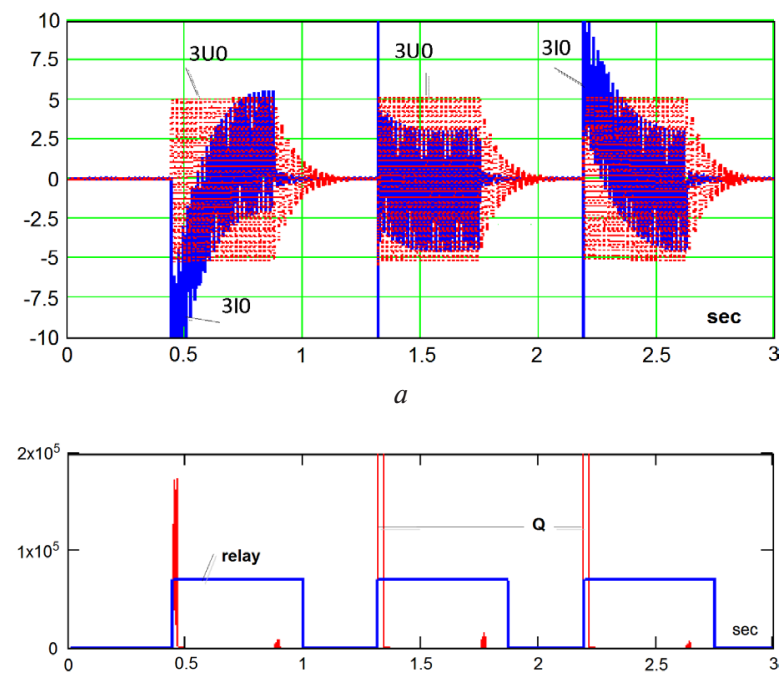

$b$

Fig. 6. The simulation results of the arc earth faults:

a-input voltage $3 U 0$ and currents 310 of a frequency of $50 \mathrm{~Hz}$ and $250 \mathrm{~Hz}$; $b$ - output pulses of reactive power and contacts relay

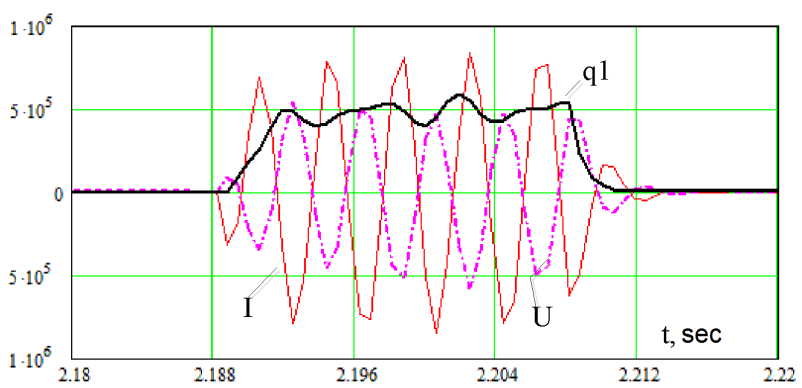

Fig. 7. The simulation results of the output protection pulse in an arc earth fault ( $U, I$-voltage and currents of a frequency of $250 \mathrm{~Hz} ; q 1$ is one of the components of reactive power)

The shape of currents and voltages at a frequency of $250 \mathrm{~Hz}$ and relay pulses are shown in Fig. 7.

The laboratory protection sample was implemented based on STM32F4Discovery microcontroller. Its satisfactory performance was achieved on a physical network model with a voltage of $0.4 \mathrm{kV}$.

In addition, verification of the operation of the protection was carried out by supplying a zero-sequence current and voltage signals recorded in a real network by digital recorders to the protection input. The results of modeling and experiments are the basis for the possibility of introducing the developed protection in electric networks with compensated neutral.

\section{Conclusions.}

1. The results of mathematical modeling showed the possibility of performing selective earth faults protection for compensated networks based on monitoring the direction of reactive power, determined by currents and voltages of a frequency of $150-300 \mathrm{~Hz}$, extracted using frequency filters from voltages and currents of zero sequence of industrial frequency. At these frequencies, the reactor inductance practically does not compensate for capacitive currents of this frequency in the damaged connection, which makes it possible to use the direction of reactive power for protection.

2. For the first time, in order to protect against phase-toground faults in compensated networks with a voltage of $6-35 \mathrm{kV}$, it was proposed to isolate frequency components higher than the industrial frequency from zero-sequence voltages and currents using the Goertzel algorithm, which is a modification of the Fourier transform, which made it possible to increase the sensitivity and speed of protection and its work stability. 
3. The effectiveness of the developed protection is confirmed by the results of mathematical modeling, laboratory tests of a full-scale sample and the correctness of the action when using signals recorded using digital recorders with earth faults in real networks.

The article is prepared based on the results of taxpayerfunded research and development project "Development of microprocessing selective earth faults protection from in conventional electric power systems and Smart-Grid systems".

\section{References.}

1. Ghaderi, A., Ginn, H. L., \& Mohammadpour, H. A. (2017). High Impedance Fault Detection: A Review. Electric Power Systems Research 143, 376-388. https://doi.org/10.1016/J. EPSR.2016.10.021.

2. Chen, K., Huang, C., \& He, J. (2016). Fault Detection, Classification and Location for Transmission Lines and Distribution Systems: A Review on the Methods. High Voltage, 1(1), 25-33. https://doi.org/10.1049/hve.2016.0005.

3. Nikiforov, A. P. (2016). Optimization of control systems in a smart grid the power grid on the basis of generalization of information flows. Tekhnichna elektrodynamika, (5), 64-66. https://doi.org/10.15407/techned2016.05.064.

4. Druml, G., Schegner, P., Fickert, L., \& Schlommer, M. (2015). Advantages of the New Combination - Petersen-Coil and Faulty-Phase-Earthing. In $23^{\text {rd }}$ International Conference on Electricity Distribution Lyon, 15-18 June 2015, (pp. 1-5). Retrieved from http://www.cired.at/pdf/CIRED2015_1450_final.pdf.

5. Ravlić, S., Marušić, A., \& Havelka, J. (2017). An Improved Method for High Impedance Fault Detection in Medium Voltage Networks. Tehnicki Vjesnik - Technical Gazette, 24(2), 391-396. https://doi.org/10.17559/tv-20151012082303.

6. Wang, X., Song, G., Chang, Z., Luo, J., Gao, J., Wie, X., \& Wie, Y. (2017). Faulty Feeder Detection Based on Mixed Atom Dictionary and Energy Spectrum Energy for Distribution Network. IET Generation, Transmission \& Distribution, 12(3), 596-606. https://doi.org/10.1049/ietgtd.2017.1250.

7. Altonen, J., Wahlroos, A., \& Vähäkuopus, S. (2017). Application of Multi-Frequency Admittance-Based Fault Passage Indication in Practical Compensated Medium-Voltage Network. CIRED - Open Access Proceedings Journal, (1), 947 951. https://doi.org/10.1049/oap-cired.2017.0967.

8. Venkataraman, K., Kirby, B., Hengxu, Ha., \& Newman, P. (2014). Transient Earth Fault Detection on Compensated Earthed System. In $12^{\text {th }}$ IET International Conference on Developments in Power System Protection (DPSP 2014), 31 March 3 April 2014. https://doi.org/10.1049/cp.2014.0034.

9. Pitot, F., \& Vassilevsky, N. (2015). Wattmetric earth fault protection - innovation for compensated distribution networks. In $23^{\text {rd }}$ International Conference on Electricity Distribution Lyon, 15-18 June 2015. Paper 0963. (pp. 1-5). Retrieved from http://cired.net/publications/cired2015/papers/CIRED2015 0963 final.pdf.

10. Syvokobylenko, V. F., \& Lysenko, V.A. (2019). Microprocessor Selective Protection from the Phase to the Earth Fault in Electric Networks with Petersen Coil in Neutral. Tekhnichna elektrodynamika, (2), 54-62. https://doi.org/10.15407/ techned2019.02.054.

11. Syvokobylenko, V. F., \& Lysenko, V.A. (2018). Use of the Fourie transform algorithm for improving phase to the earth fault protection in distribution electric networks. Naukovi pratsi Donetskoho natsionalnoho tekhnichnoho universytetu. Seriia "Elektrotekhnika $\boldsymbol{i}$ enerhetyka", 1(19) 2(20).

12. Galanina, N.A., Dmitriev, D. D., \& Akhmetzyanov, D. I. (2013). Goertzel algorithm for signals spectral analysis. Software systems and computational methods, 4, 376-383. https:// doi.org/10.7256/2305-6061.2013.4.10543.

\section{Захист від замикань на землю в компенсованих електричних мережах на основі частотних фільтрів}

\author{
В. Ф. Сивокобиленко, В. А. Лисенко
}

Донецький національний технічний університет, м. Покровськ, Донецька обл., Україна, e-mail: svf1934@gmail. com; viktor.lysenko@donntu.edu.ua

Мета. Розробка селективного мікропроцесорного захисту від замикання фаз на землю в компенсованих електричних мережах 6-35 кВ. Використання алгоритму Гертцеля для виділення із напруг і струмів нульової послідовності складових більш високих частот, ніж промислова

Методика. Використовуються методи математичного моделювання та аналізу перехідних процесів у компенсованих електричних мережах 6-35 кВ, перетворення Фур' $€$ та алгоритм Гертцеля, побудова алгоритмів захисту від замикань на землю, експериментальні дослідження.

Результати. Результати математичного моделювання показали, що в компенсованих мережах напругою 6-35 кВ при замиканні фаз на землю напрям реактивної потужності нульової послідовності в пошкодженому приєднанні може бути таким же самим, як і в непошкодженому, що унеможливлює селективну дію реле потужності. Таку дію може забезпечити захист на основі напряму реактивної потужності, що розраховується за допомогою складових фіксованої частоти в межах 200-300 Гц. Реактивна потужність для них у пошкодженому приєднанні завжди спрямована від шин, оскільки практично не компенсується реактором незалежно від ступеня його налаштування. При використанні смугових частотних фільтрів необхідна чутливість захисту не завжди забезпечується при замиканні фази на землю через опори, що перевищують 10-15 Ом. Також можливе порушення стійкої роботи фільтрів через розташування їх полюсів на окружності з одиничним радіусом, а застосування блоків чисельного диференціювання струмів і напруг може призвести до збоїв у роботі при дугових замиканнях на землю, що перемежовуються. Запропоновано застосування алгоритму Гертцеля для виявлення складових підвищених частот. Він реалізований у формі фільтра 3 нескінченною імпульсною характеристикою другого порядку із двома дійсними коефіцієнтами в колі зворотного зв'язку та одним комплексним коефіцієнтом у колі прямого зв'язку. Результати моделювання поведінки захисту в системі комп'ютерної алгебри Mathcad підтвердили скорочення розрахункових витрат і його стабільну роботу незалежно від наявності аперіодичних складових у струмі за різних початкових фаз напруги в момент замикання. У складі захисту передбачено пусковий орган, що дозволяє роботу захисту, якщо напруга нульової послідовності перевищує задану уставку, що становить 12-15\% від номінального значення. Для забезпечення надійної роботи захисту як при стабільних, так і при дугових замиканнях передбачено автоматичне підхоплення імпульсів захисту при появі замикання. Отримані позитивні результати роботи алгоритму захисту на математичній моделі мережі, а також на лабораторній установці зразка, реалізованого на мікропроцесорній основі.

Наукова новизна. Уперше для захисту від замикання фази на землю в компенсованих мережах напругою 6-35 кВ запропоновано виділяти з напруг і струмів нульової послідовності складові частоти вище промислової за допомогою частотних фільтрів, заснованих на алгоритмі Гертцеля, які є вдосконаленим перетворенням Фур'є, що дозволило підвищити чутливість, швидкодію захисту та стабільність його роботи. 
Практична значимість. Математична модель компенсованої електричної мережі дозволяє аналізувати поведінку захисту при глухих і дугових замиканнях на землю. Розроблений селективний захист від замикань на землю дозволяє підвищити надійність роботи систем електропостачання $6-35 \mathrm{kB}$.

Ключові слова: компенсована мережа, математична модель, замикання на землю, селективний захист, частотний фільтр, перетворення Фур'є, алгоритм Гертиеля

\section{Защита от замыканий на землю в компенсированных электрических сетях на основе частотных фильтров}

\section{В. Ф. Сивокобыленко, В.А. Лысенко}

Донецкий национальный технический университет, г. Покровск, Донецкая обл., Украина, e-mail: svf1934@ gmail.com; viktor.lysenko@donntu.edu.ua

Цель. Разработка селективной микропроцессорной защиты от замыканий фазы на землю в компенсированных электрических сетях 6-35 кВ. Использование алгоритма Гертцеля для выделения из напряжений и токов нулевой последовательности составляющих более высокой частоты, чем промышленная.

Методика. Используются методы математического моделирования и анализа переходных процессов в компенсированных электрических сетях 6-35 кВ, преобразование Фурье и алгоритм Гертцеля, построение алгоритмов защиты от замыканий на землю, экспериментальные исследования.

Результаты. Результаты математического моделирования показывают, что в компенсированных сетях напряжением 6-35 кВ при замыканиях фазы на землю направление реактивной мощности в поврежденном присоединении может быть таким же, как и в неповрежденном, в связи с чем конвенциональные защиты не могут обеспечивать селективного действия. Такое действие могут обеспечить защиты, основанные на выделении из напряжений и токов нулевой последовательности их составляющих с фиксированной частотой, взятой из диапазона 200-300 Гц. Реактивная мощность для них в поврежденном присоединении всегда направлена от шин, так как практически не компенсируется реактором независимо от степени его резонансной настройки. При применении полосовых частотных фильтров требуемая чувствительность защиты не всегда обеспечивается при за- мыкании фазы на землю через сопротивления, превышающие 10-15 Ом. Кроме того, возможно нарушение устойчивой работы фильтров из-за расположения их полюсов на окружности с единичным радиусом, а применение блоков численного дифференцирования токов и напряжений может привести к сбоям в работе при перемежающихся дуговых замыканиях на землю. Предложено применение алгоритма Гертцеля для выделения составляющих повышенной частоты. Он реализован в форме фильтра с бесконечной импульсной характеристикой второго порядка с двумя действительными коэффициентами в обратной связи и одним комплексным коэффициентом в цепи прямой связи. Результаты моделирования поведения защиты в системе компьютерной алгебры Mathcad подтвердили сокращение расчетных затрат и её стабильную работу независимо от наличия апериодических составляющих в токе при разных начальных фазах напряжения в момент замыкания. В защите предусмотрен пусковой орган, разрешающий работу защиты, если напряжение нулевой последовательности превышает заданную уставку, равную $12-15 \%$ от номинального. Для обеспечения надежной работы защиты, как при устойчивых, так и при дуговых замыканиях, предусмотрен автоматический подхват импульса срабатывания защиты при появлении замыкания. Получены положительные результаты работы алгоритма защиты на математической модели сети, а также на лабораторной установке образца, реализованного на микропроцессорной основе.

Научная новизна. Впервые для защиты от замыкания фазы на землю в компенсированных сетях напряжением 6-35 кВ предложено выделять из напряжений и токов нулевой последовательности составляющие частоты выше промышленной с помощью частотных фильтров, основанных на алгоритме Гертцеля, являющегося усовершенствованным преобразованием Фурье, что позволило повысить чувствительность, быстродействие защиты и стабильность её работы.

Практическая значимость. Математическая модель компенсированной электрической сети позволяет анализировать поведение защиты при глухих и дуговых замыканиях на землю. Разработанная селективная защита от замыканий на землю позволяет повысить надежность работы систем электроснабжения 6-35 кВ.

Ключевые слова: компенсированная сеть, математическая модель, замыкание на землю, селективная защита, частотный фильтр, преобразование Фурье, алгоритм Гертцеля

Recommended for publication by O.P. Chornyi, Doctor of Technical Sciences. The manuscript was submitted 29.03.19. 